\title{
Foreign Direct Investment as a Factor of Diminishing OR/AND InCREASING Regional INEQUALITIES? ${ }^{1}$
}

\author{
Igor SîRodoev, Ioan IANoș, both Bucharest [Bucureşti], George White, \\ Brookings (South Dakota, United States), and Daniel VîRDol, \\ Bucharest*
}

with 7 figures and 2 tables in the text

\section{Content}

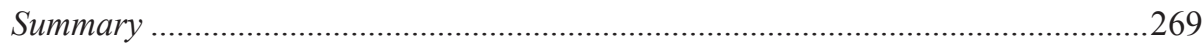

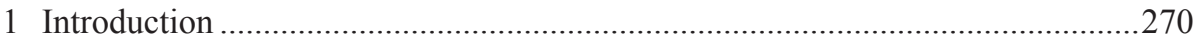

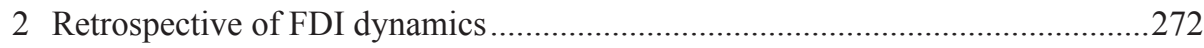

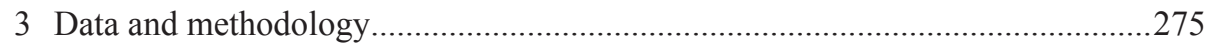

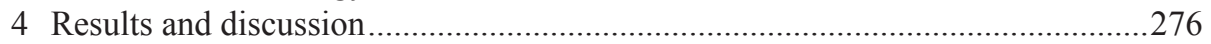

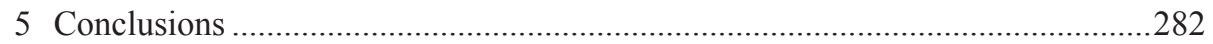

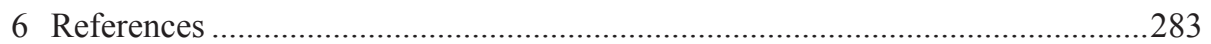

\section{Summary}

Foreign Direct Investment (FDI) has positive effects in well-established market economies, but its effects in transition countries are less clear. For the former 1 The paper is a partial result of the research within the projects ESPON GROSSE "Emergence of Growth Poles Network in South-East Europe" and UB no.1322/2012 “Integrated and sectoral analyses in trans-scalar territorial dynamics". This work was supported by a grant of the Romanian National Authority for Scientific Research and Innovation, CNCS - UEFISCDI, project number PN-II-RU-TE-2014-4-1481.

* Dr. Igor Sîrodoev and Prof. Dr. Ioan Ianos, both University of Bucharest, Interdisciplinary Centre for Advanced Research on Territorial Dynamics, 4-12 Regina Elisabeta Bld., sector 3, RO-030018 Bucharest; email: ingvarr_i@yahoo.com, ianos50@yahoo.com,www.cicadit.ro; Prof. Dr. George Whiтe, Department of Geography, Wecota Hall, 109, Box 506, South Dakota State University, 57007 Brookings (SD), United States; email: george.white@sdstate.edu; Dr. Daniel VîRDOL, Institutul National de Studii, 16 Libertatii Bld. Sector 5, RO-050706 Bucharest; email: danielv@insse.ro 
Communist countries of Central and Eastern Europe, the role of FDI varies depending on the phase of transition. Central and Eastern European countries are especially vulnerable in the early stages of transition because the introduction of FDI adds further disturbances to the process of post-Socialist restructuring. Most Central European countries successfully passed this period, but a few of them and the majority of Eastern Europe countries are still vulnerable to FDI's negative effects. Among such effects are FDI's unclear impacts on economic growth, the lack of connections between FDI, exports, and economic growth, the absence of linkages with local economies, and the increase in regional inequalities. Assessments suggest that Romania is one of the countries that suffer from these effects because its economic transition is incomplete. A detailed analysis provides evidence of FDI's regional impacts within Romania. FDI has contributed to increasing regional imbalances in economic development rather than promoted economic stability by helping the lesser-developed areas catch-up to the richer ones. Nevertheless, FDI's structure and volume could reduce regional disparities during economic boom periods through a generalised, spatial spreading of growth. However, from 2000 to 2008, FDI played an important role in the evolution of spatial disparities among Romania's regions. No changes occurred to the hierarchy of regions in regard to attracting FDI, but there is an interesting trend to reduce the existing regional decay. During the financial-economic crisis that began in 2008, large urban agglomerations proved that they played an important role in conserving precrisis trends. Some foreign investments were redirected to their originating countries while others simply diminished. As a result, large cities increased their share of the total national volume of FDI.

\section{Introduction}

Foreign Direct Investment (FDI) plays a significant role in modern economies. Despite the global, financial-economic crisis that began in 2008, the practice of liberalizing FDI policies to stimulate growth continued. For example, global foreign direct investment flows reached 1.5 trillion USD in 2011, which exceeded the precrisis average (UNCTAD 2012).

FDI's increase in 2011 was differentiated by regional groupings of countries. Developed countries, accounting for $49 \%$ of global FDI flows, experienced a $21 \%$ increase in inward investment. In contrast, developing countries, with $45 \%$ share of the global figure, had only an $11 \%$ increase in investment flows. The greatest growth rates were seen in transition countries, which had a $25 \%$ increase. However, they attracted just $6 \%$ of total global FDI flows. According to the World Investment Report's forecasting, transition economies will exceed the highest levels of FDI, which were recorded in 2007, if the current trend continues in 2014 (UNCTAD 2012). 
Considering the impact of FDI on the economic performances of various countries, the highest economic development impact - measured in GDP growth 'per unit of FDI' - was seen in several developing and transition countries, namely Argentina, Bolivia, Colombia, Brazil, China and Romania (UNCTAD 2012).

The UN Conference on Trade and Development (UNCTAD) has made three assertions concerning FDI: (a) foreign direct investment could be a key element for re-launching economic development in countries hardly affected by the 2008 financial crisis; (b) transition economies were the most successful in attracting FDI flows during the global-financial crisis; (c) Romania is one of the countries where the contribution of FDI to economic growth was the highest in 2011.

UNCTAD assertions concerning the benefits of FDI do not accurately represent the experiences of transition countries. Central and East European countries were vulnerable in the early phases of transition, when the addition of FDI into this region increased disturbances into the process of post-Socialist restructuring. The performance of FDI is highly dependent on many factors (BEYER 2002), among the most important are transition-specific (privatisation, reconversion etc.). These factors vary along each country's path from state-planned to market economy (LEFILLEUR 2008) and can be generalised into phases. With each phase noteworthy for differing levels of FDI attraction and performance, the phase of transition becomes crucial when analysing and considering the effects of FDI (HoLLAND et al. 2000). Romania is a very conspicuous example of these variations because it has experienced a very difficult and delayed transition. Earlier modeling results showed no clear impact of FDI on GDP though measured in various ways (BotRIC \& SKUfLIC 2006). However, more recent studies (Roman \& Padureanu 2012; Hudea Caraman \& Stancu 2012) and the World Investment Report (UNCTAD 2012) concurred that foreign direct investment had a strong, positive effect on Romania's economy.

Foreign direct investment has a positive role in regional development (BAILEY \& DRIFFIELD 2002). However, the scientific literature reports that FDI has had highly controversial and some negative impacts on regional and local economies in transition countries especially in early phases of transition (SMith \& FerenČíKová 1998, DE BACKer \& Sleuwagen 2003). For example, it intensifies uneven development, fosters the creation of dual economies, prevents the development of linkages between local and regional economies, and overall increases regional economic instability (PAVLINEK 2004). Because the most recent statistical reports (UNCTAD 2012) show that FDI in Romania is higher than in classically developed countries, FDI has been at significant enough levels to be a factor in increasing regional inequalities within Romania. How this has occurred during the financial crises is also noteworthy. 


\section{Retrospective of FDI dynamics}

The entire post-Socialist development of Romania was dominated by two main phenomena: economic restructuring (de-industrialisation and privatisation) and the attraction of foreign direct investment. Of the two, the latter was strongly dependent on the former (Kalotay \& Hunya 2000). New direct investments were extremely important for facilitating the economic restructuring needed for the transition to a market economy. Foreign direct investment played a key role in this process because Romania lacked the entrepreneurial culture and experience necessary for the formation of a strong local-investor class (IANOș 2010). However, the absence of political credibility and stability delayed strategic investment externally (IANoș \& GuRAn 1993). Although Central European countries only were somewhat successful in initially obtaining FDI in the 1990s (KALOTAY 2000), Romania waited longer than the others to gain higher levels of FDI. At the beginning of the 1990s, the main obstacles were the continued domination of a state-run economy (GURAN 2002). After a slow start in the 1990s, inward FDI experienced quite a strong rise in the late 1990s-early 2000s thanks to massive privatisation of state-owned enterprises. The slowdown occurred after 2007 caused by diminution of the stock of state enterprises (PAUWELS \& IONIȚA 2008).

Figure 1: Romanian counties and Romania's position in Europe (box)

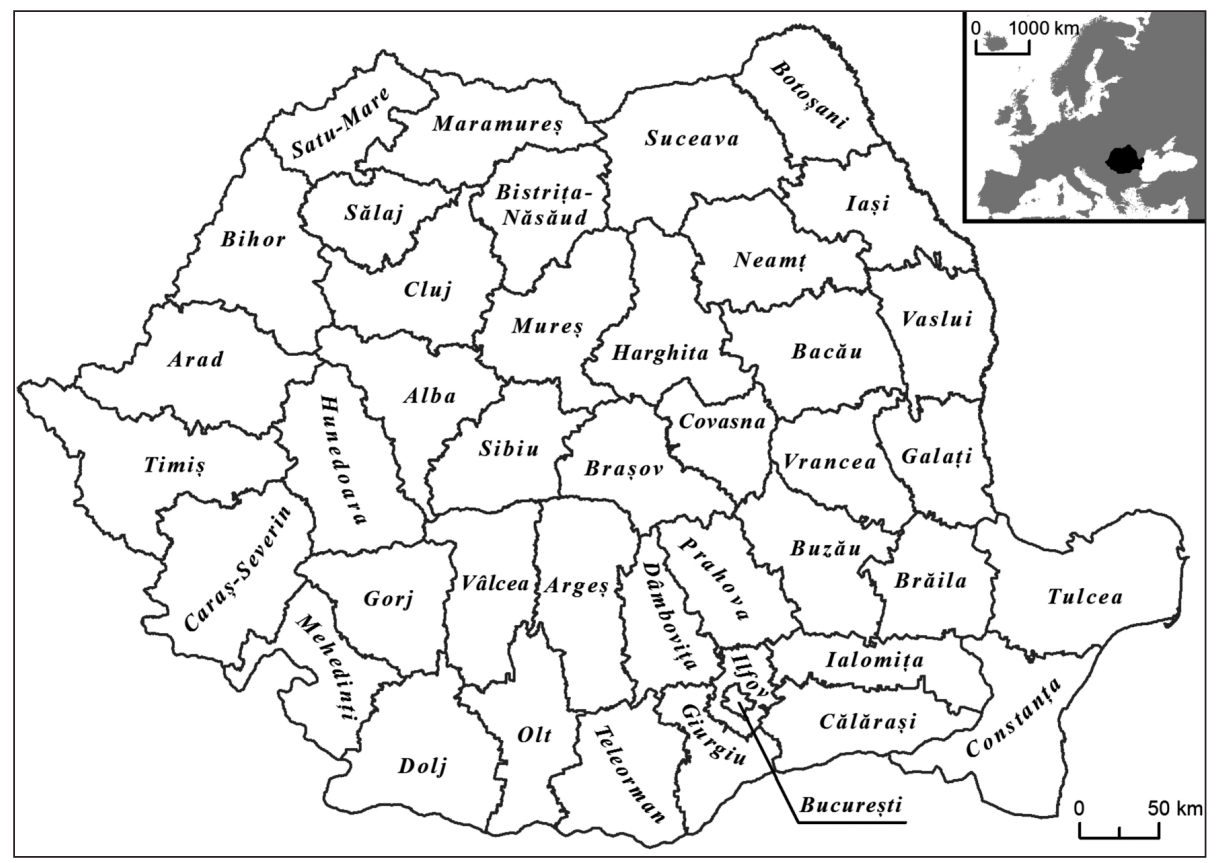


In its post-Communist history, Romania registered several periods in which the dynamics of FDI changed quite dramatically at certain points, which in turn mark the boundaries of distinct phases:

(a) 1989-1997: small investors and low investment flow;

(b) 1998-2003: "significant investors," marked by sums of greater than 1 billion USD of inward FDI flow per year (PĂUNA \& ANDREI 2004);

(c) 2004-2008: Romania's joining of NATO and accession to EU strongly influenced inward FDI in Romania (IANOș 2010);

(d) 2009-present: the global financial-economic crisis that caused the reduction of inward FDI flows with the strongest declines recorded in Romania's postCommunist history. However, FDI inflows varied greatly at the regional level. Some counties, for example Vrancea and Vâlcea, showed significant declines in inward FDI stock, 60\% and more than 30\% respectively (Fig. 1). Others, such as Bihor, Bistrița-Năsăud, Buzău and Giurgiu, received more than tripling of stock investment, namely $247 \%, 256 \%, 281 \%$, and $437 \%$ respectively.

Figure 2 illustrates FDI relative to GDP growth rates for periods since 2000. GDP growth rates clearly show a strong variation by period. FDI is less obvious with no spectacular growth rate values occurring during the global financial crisis. But both indicators could be considered the most important for measuring the level of regional development (IANOș et al. 2013).

Figure 2: Yearly growth rates by periods: FDI vs. GDP

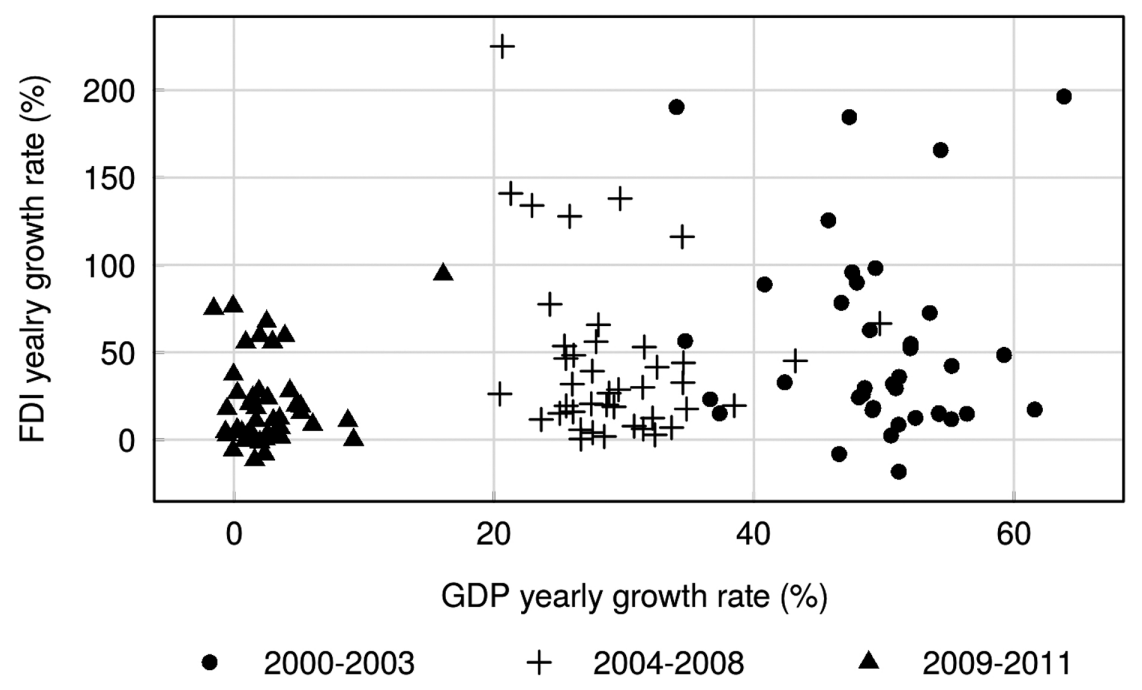


Note: Four counties (Galați, Dâmbovița, Teleorman, Mehedinți) having more than $300 \%$ yearly growth rates in 2000-2003 are not shown for that period.

According to data from the National Trade Register Office, total inward FDI stock grew by 3.68 billion USD in 2012, which represented about $2.1 \%$ of Romanian GDP. Spatially, the highest concentrations of FDI were found in Bucharest-Ilfov, West, and North-West development regions (KURKO 2006). This distribution seems to reflect findings of studies at the country level: proximity to EU (core EU) countries (BEVAN \& Estrin 2004; Kitonakis \& Kontis 2008; Serbu 2005) and the agglomeration effect (Hilber \& Voicu 2010).

From a structural perspective, each economic sector has varied in its ability to attract FDI. In particular, processing has been one of the more successful ones within the industrial sector. However, FDI flows have been directed towards the sectors with moderate and low technological levels (ZAMAN et al. 2011). Only since 2008 have new trends appeared in which FDI flows have switched from the lower end of the value chain (e.g., textiles and leather) towards services and higher value-added manufacturing (PAUwELS \& IONIȚĂ 2008).

Table 1 illustrates the economic sectors that have received FDI and how FDI flows to the various sectors have changed over time.

Table 1: Distribution of inward FDI stock by economic activities

\begin{tabular}{|c|c|c|c|}
\hline \multirow{2}{*}{ Main economic activities } & \multicolumn{3}{|c|}{$\%$ from TOTAL } \\
\hline & 2003 & 2008 & 2013 \\
\hline Industry & 51.1 & 41.3 & 48.1 \\
\hline Mining & 0.2 & 4.4 & 5.9 \\
\hline Manufacturing industry & 50.9 & 31.2 & 31.1 \\
\hline - food, drinks, and tobacco & 9.7 & 4.5 & 4.0 \\
\hline - cement, glass, and ceramics & 4.6 & 3.6 & 2.7 \\
\hline - woodworks, including furniture & 2.8 & 1.8 & 2.1 \\
\hline - computers, other electronics, optics and electrics & 2.3 & 1.4 & 2.1 \\
\hline - machinery and equipment & 4.5 & 2.0 & 2.2 \\
\hline - metallurgical engineering & 11.6 & 6.9 & 4.1 \\
\hline - vehicles & 5.5 & 4.0 & 5.7 \\
\hline - petrol refining, chemical products, rubber, and plastics & 4.1 & 4.3 & 5.9 \\
\hline - textiles, apparel, and leather & 4.4 & 1.6 & 1.5 \\
\hline - other branches of manufacturing industry & 1.4 & 1.0 & 0.8 \\
\hline
\end{tabular}




\begin{tabular}{|l|r|r|r|}
\hline \multirow{2}{*}{ Main economic activities } & \multicolumn{3}{c|}{$\%$ from TOTAL } \\
\cline { 3 - 4 } \multicolumn{1}{|c|}{} & \multicolumn{2}{|c|}{$\mathbf{2 0 0 3}$} & \multicolumn{2}{|c|}{$\mathbf{2 0 0 8}$} & \multicolumn{1}{|c|}{$\mathbf{2 0 1 3}$} \\
\hline Electric energy, gas, and water* & & 5.6 & 11.1 \\
\hline Professional and other activities and supporting services* & 3.3 & 5.0 \\
\hline Agriculture, forestry, and fishery* & & 1.4 & 2.1 \\
\cline { 3 - 4 } & & 0.3 & 0.5 \\
\hline Other economic activities & 11.4 & 12.4 & 11.2 \\
\hline Trade & 9.2 & 12.6 & 9.8 \\
\hline Constructions, real estate and other services for enterprises & 1.1 & 0.4 & 0.6 \\
\hline Hotels and restaurants & 9.1 & 20.5 & 14.2 \\
\hline Financial operations and insurance & 14.8 & 6.7 & 6.9 \\
\hline Information and communication technologies & 1.4 & 1.0 & 1.6 \\
\hline Transportation & 100.0 & 100.0 & 100.0 \\
\hline TOTAL & $\mathbf{9 , 6 6 2}$ & $\mathbf{4 8 , 7 9 8}$ & $\mathbf{5 9 , 9 5 8}$ \\
\hline TOTAL, mil. EUR & & & \\
\hline
\end{tabular}

Source: NATiOnaL BANK OF Romania

\section{Data and methodology}

As stated previously, the size of the economy/market of a region is one of the drivers for FDI. To measure the strength of the relationship between FDI and the size of regional economies/markets in Romania, the 42 counties [judeţ] of Romania were used as units of analysis. The economy/market size of the counties was expressed by their annual GDP. Data on foreign direct investment and companies by economic sector was collected from the Romanian National Office of Trade Register. The source for statistical data on GDP and population characteristics were collected from the Romanian National Institute of Statistics. All data were collected for the period between 2000 and 2011, which includes the most recently available GDP data.

A bivariate regression analysis was employed to identify the relationship between regional FDI stock and such variables as regional GDP, urban population, and countyseat population (the latter two measured in number of inhabitants) to signify the sizes of regional economies. Two extremes strongly influenced the distribution curve. Bucharest had the highest FDI and GDP values and Gorj County had the lowest (Fig. 3 ). Although these extremes were removed from further analysis, a normal distribution curve did not emerge. Subsequently, logarithmic values were employed in the analysis of the variables. 
Figure 3: Yearly relationships FDI vs. GDP for the years 2000, 2002-2011

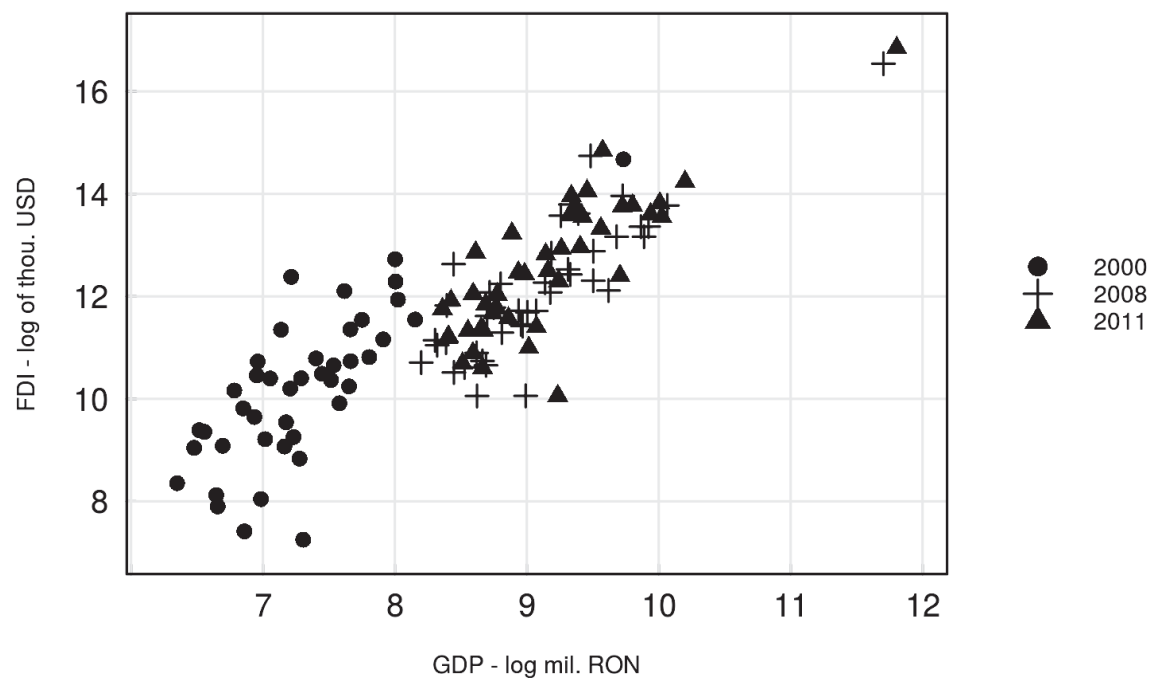

$\beta$-convergence (BARro \& SALA-I-MARTIN 1992, 2004) was used to test whether the dynamics of FDI and GDP were convergent or divergent during the study periods.

The Gini index was used for measuring regional imbalances in FDI and GDP. This method was employed to determine whether FDI contributes to increasing imbalances in economic development of the regions or it is a factor of stability, in turn helping the less developed regions to catch-up the richest ones.

\section{Results and discussion}

The results of the regression analyses indicate that FDI stock depends on the size of regional units (counties). However, the relationship is not very strong, though it is significant, and varies over time (Fig. 4). Thus, the strongest relationship exists with county GDP. However, the strength of this relationship diminished during the period of relative prosperity (2004-2008). It indicates that development characteristics (including attractiveness for FDI) spread from stronger to weaker regional economies. The period of the global-financial crisis is too short to be definitive in this regard. Nevertheless, the size of regional economies seems to be important for attracting FDI.

The size of populations seems to be less significant than the size of regional economies in attracting FDI. In recent years, the urban populations of counties are 
responsible for attracting FDI in approximately $50 \%$ of the cases. Neither seats of the counties are an important determinant of FDI.

Figure 4: Variation of the strength of relationship FDI vs. GDP, urban population and number of population in counties' seats (r-sq. adjusted of paired regressions)
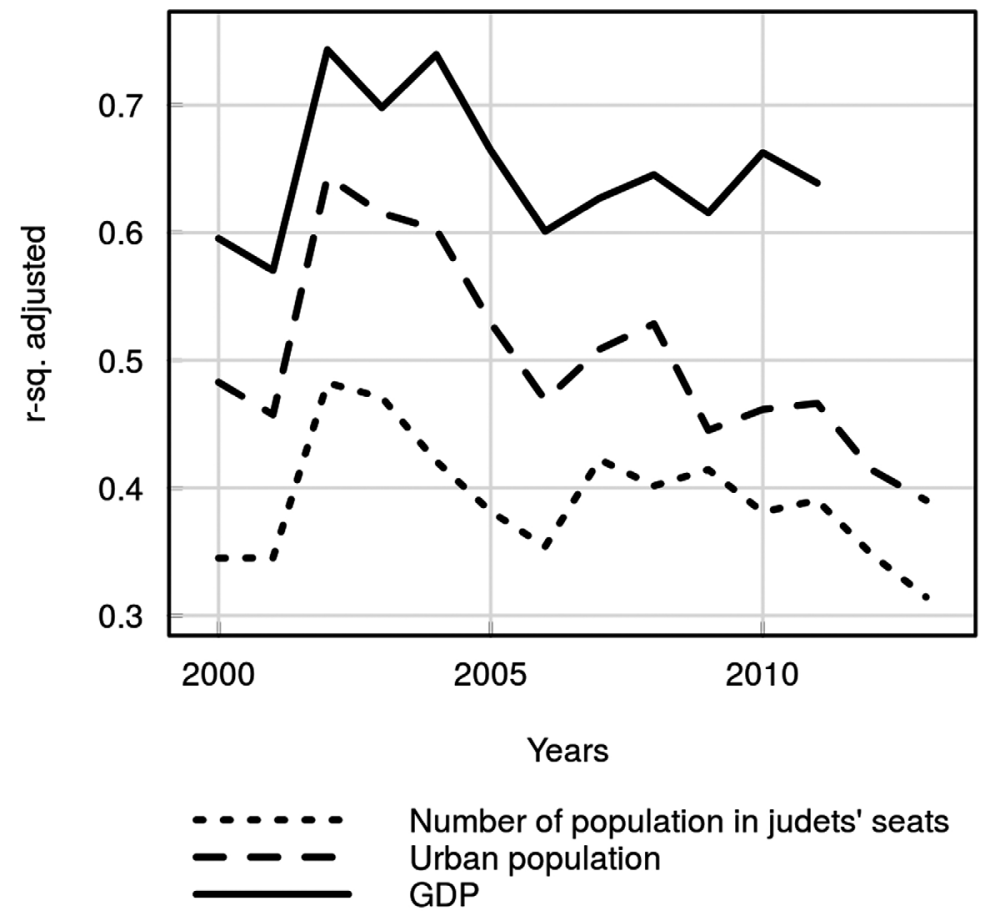

In the 2000-2003 period, the highest growth rate was shown in Galați County, which recorded a yearly average of more than $1,000 \%$. This was due to the privatisation of the Galați steel plant. A number of counties with low GDPs registered vastly different FDI growth rates. For example, Alba, Bistriţa-Năsăud, Covasna, and Harghita Counties received about 960 million RON on average and registered approximately $9 \%$ annual FDI growth rates. In contrast, Mehedinți and Teleorman Counties received 968 million RON on average, but these sums represented a tripling of the annual FDI that they received during this period. Among the strongest regional economies were Argeș, Braşov, Cluj, Constanța, Prahova and Timiș Counties. They experienced an average of $68 \%$ annual increases in FDI.

In the 2004-2008 period, FDI growth rates were not as remarkable as in the previous period. In this period, Gorj County led the other counties in FDI growth, about 2.25 times per year. Also, the size of each region's economy was not necessarily 
a determinant for FDI growth. Some counties that had low- to medium-sized GDPs in 2003 (3.8 billion RON on average) showed very low FDI growth rates, 7\% on average. Examples of these counties include Arad, Dâmbovița, Dolj, Galați, Maramureș, and Vâlcea. In contrast, counties with smaller GDPs (2.4-2.5 billion RON) displayed much higher figures of investment growth. Brăila, Covasna, Harghita, and Vaslui recorded approximately $21 \%$ growth, and Alba, Botoșani, Buzău, Giurgiu, and Olt registered $48 \%$ growth. The larger counties were divided into three groups. Cluj, Constanța, Prahova, and Timiş had the lowest FDI growth rates with $11 \%$ on average. Argeș, Bihor, Hunedoara, Iași, and Sibiu showed better results with $26 \%$ growth rates. The third group was comprised of Brașov, Ilfov, and Tulcea Counties, which performed better in FDI attraction.

In the 2009-2013 period, which is noted for the beginning of the financialeconomic crisis, the weaker counties continued to show variations in FDI dynamics. Very slow growth $(2.4 \%)$ was seen with counties such as Caraș-Severin, Harghita, Mehedinți, and Sălaj. In contrast, Brăila, Călărași, Ialomița and Tulcea Counties recorded growth rates that averaged $16.5 \%$. The highest growth figures occurred in the medium to low economies (Alba, Bihor, Bistrița-Năsăud, Giurgiu). Some of the strong economies (Argeș, Maramureș and Vâlcea) comprised a group with a significant decreasing trend of FDI $(-13 \%)$. Other strong counties clearly manifested positive dynamics during the crisis: Cluj, Constanța, Iași, Prahova, and Timiș (18\% FDI annual growth rates).

Bucharest was never the leader in FDI multiplication as it showed rather moderate growth rates (33\% in 2000-2003; 45\% in 2004-2008, and $16 \%$ in 2009-2010).

$\beta$ convergence analysis indicates a strong converging trend in the period 20002003 thanks to very high FDI-growth rates in weaker economies, especially Galați, Dâmbovița, Teleorman and Mehedinți Counties (Table 2). In the next period (20042008), known for its relative prosperity, this trend continued but became less evident. During the financial-economic crisis (2009-2011), the situation became unclear and cannot be labeled as either convergent or divergent (Fig. 5).

Table 2: Beta convergence indexes for FDI

\begin{tabular}{|c|r|r|r|l|l|}
\hline Period & \multicolumn{1}{c|}{ Index } & $\begin{array}{c}\text { r-sq. } \\
\text { adjusted }\end{array}$ & p-value & \multicolumn{1}{|c|}{ Significance } & \multicolumn{1}{|c|}{ Interpretation } \\
\hline $2000-2003$ & -0.53 & 0.09 & 0.027 & significant & convergence \\
\hline $2004-2008$ & -0.18 & 0.19 & 0.002 & significant & convergence \\
\hline $2009-2013$ & -0.03 & -0.01 & 0.393 & not significant & convergence? \\
\hline $2000-2013$ & -0.49 & 0.20 & 0.002 & significant & convergence \\
\hline
\end{tabular}

Source: calculated by authors 
Figure 5: Beta convergence of registered capital per capita in Romanian counties

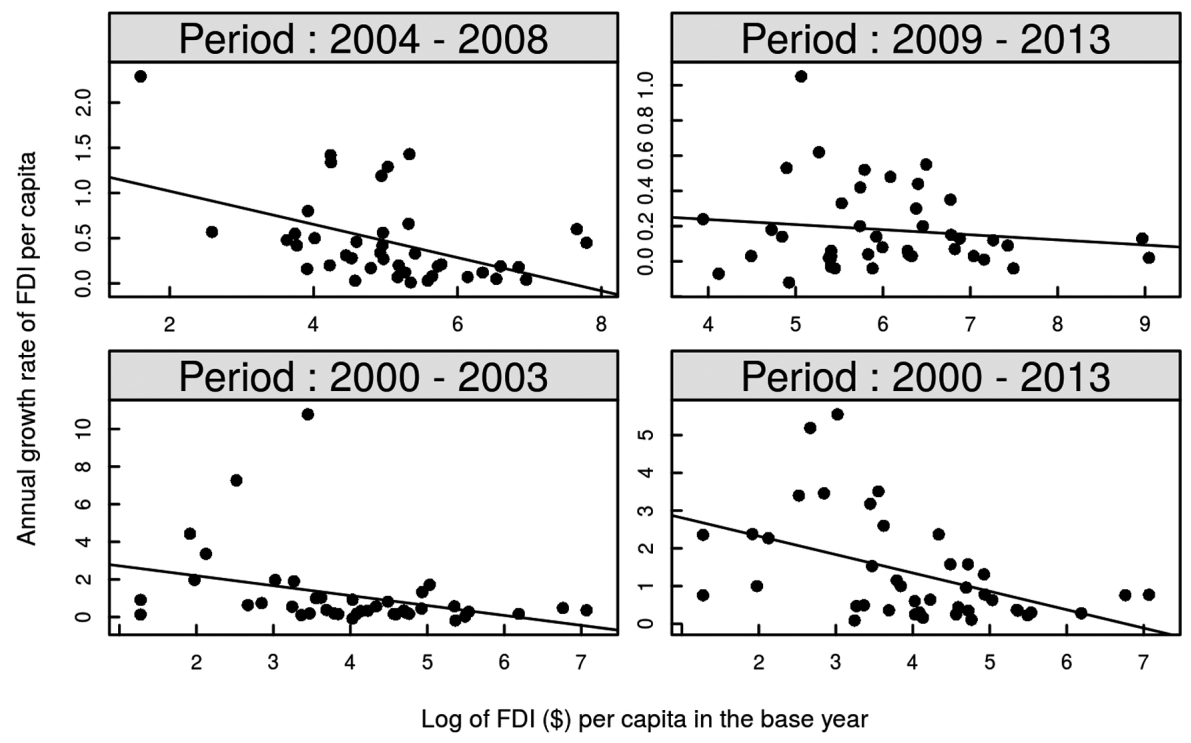

As the Gini index shows, GDP is much less concentrated than FDI. Moreover, no similarities exist in the dynamics of GDP and FDI variables in 2000s (Fig. 6). Before 2004, inequalities in GDP distribution among counties remained mostly unchanged. In the period of prosperity (2004-2008), a clear but relatively weak trend of increasing imbalances in regional economies expressed itself. This trend corresponds to the regional effect of the first phase of FDI, which is marked by increasing inequalities and is accentuated by a strong agglomeration effect (DAMIJAN \& Kostevic 2011). This analysis shows that this effect was not that strong in Romania. Moreover, once the crisis came, imbalances remained unchanged but at a higher level than previously.

Concurrently, the number of companies benefitting from FDI contributed to a persistent trend that reduced regional imbalances since the beginning of the 2000s. With regard to FDI stock, the dynamics could not be clearly divided by this study's periods. Before 2003, strong investments in several counties (i.e., Galați, Dâmbovița, Teleorman, and Mehedinţi) were meant to reduce imbalances in FDI distribution (GURAN 2000). The period of relative prosperity (2004-2008) started with sharp increases in the imbalances, pointing to the role of several (economically strong) counties in attracting FDI. It then continued with a relatively weak trend of declining imbalances until its end. The financial-economic crisis started with a significant decline in the inequalities (in 2009), suggesting that counties with stronger economies were more affected by the crisis. In 2010, the trend reversed, indicating that stronger counties were faster to adapt to the crisis than counties with weaker economies. 
Figure 6: Change of Gini index for regional GDP, number of companies benefited from FDI and yearly inward FDI stock: left panel - 40 counties plus Ilfov County and Bucharest Municipality; right panel - 40 counties without the latter two

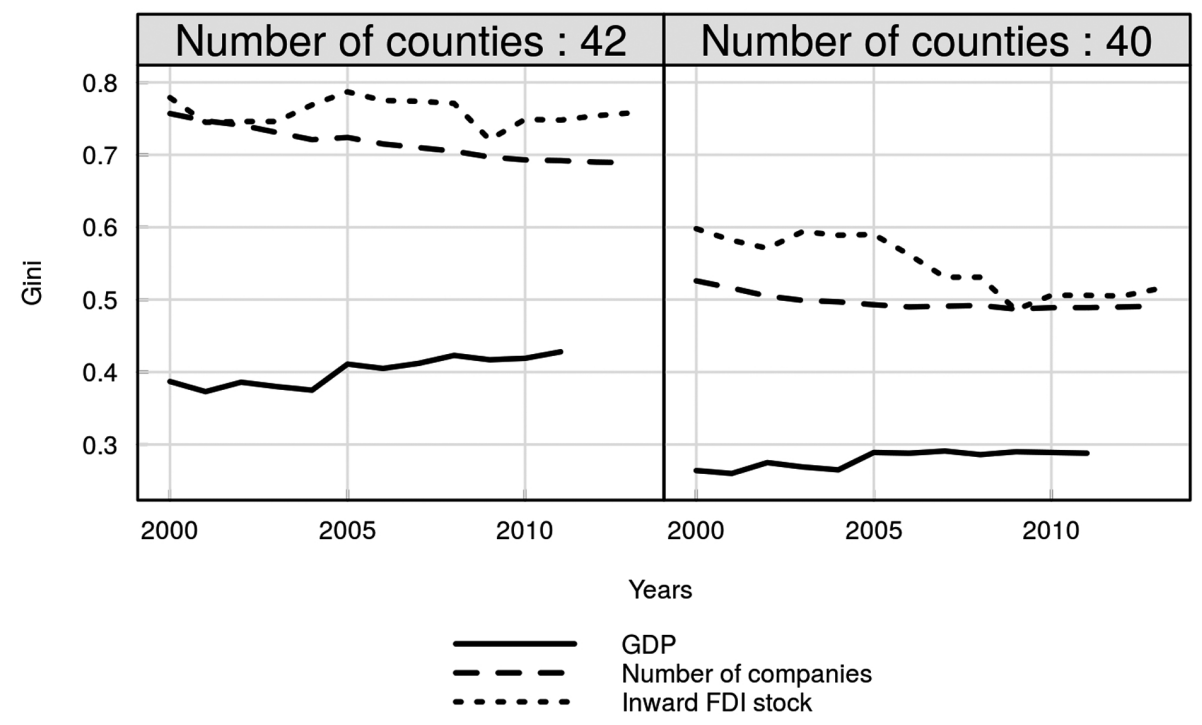

From 2000 to 2003, the rank difference analysis shows quite a stable situation in the upper half of the hierarchy of the counties, which contrasts was is revealed in the lower half of the hierarchy (Fig. 7). In the period of relative prosperity (2004-2008), changes in the ranks were more significant and affected all counties; however, more remarkable changes occurred in middle and lower parts of the hierarchy. The period of the financial-economic crisis shows similar active changes in rankings, as in the previous period. However, the middle part of the county hierarchy experienced fewer variations than the upper-middle and lower segments.

Common characteristics of the three analysed periods suggest a relative stability in the upper and middle parts of the hierarchy. The tail of the distribution is dominated by more positive than negative changes.

At the regional (county) level, foreign direct investment is highly affected by large, individual projects such as green-field investments and the privatisation of large enterprises. These projects sharply increase the share of foreign capital in regional economies. However, after these one-time investments, further FDI growth is subject to general, base-line, conditions. It means that sharp increases of FDI stock in these situations do not attract other investments into a region. The case of Gorj County is quite exemplary, being specialised in the mining industry. Consequently, the analysis of 
Figure 7: Rank difference for inward FDI stock by counties

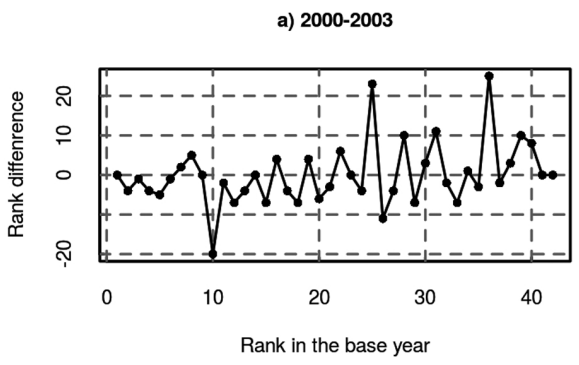

c) $2009-2013$

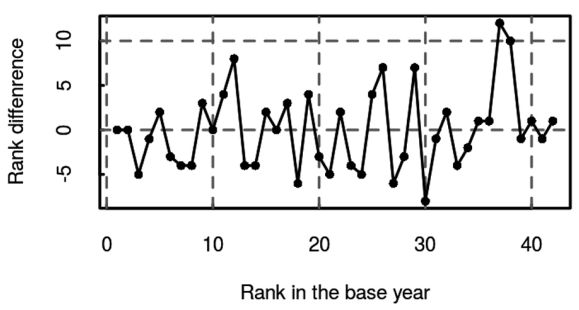

b) 2004-2008

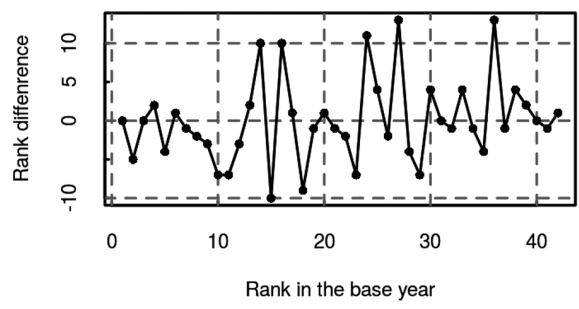

d) 2000-2013

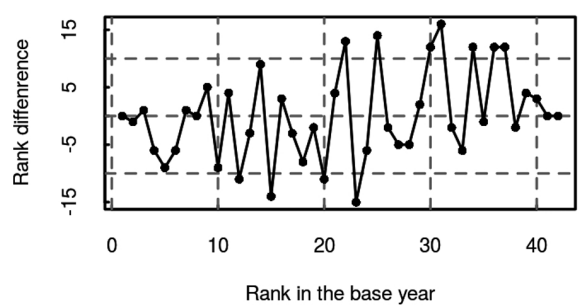

generalised figures over several years does not necessarily reflect annual performances of regional economies. Nevertheless, this analysis has contributed to the identification of certain trends.

In Romania, FDI correlates weakly with GDP, and divergent trends of the Gini coefficient are present. This indicates that the strengths of individual regional economies do not determine the destinations of FDI though regional economies receive two-thirds of Romania's FDI. Neither the sizes of urban population nor those of county seats play an important role in attracting FDI. The example of Iași County compared to either Timiș or Constanța Counties sufficiently illustrate this finding. Despite quite weak correlations in the p-value of the models, which show less than 0.05 in all the cases, they seem significant. Thus, our findings do not contradict other results that emphasise the role of market size in FDI attraction (BEVAN \& Estrin 2004; CASI \& RESMINI 2010; Clausing \& Dorobanțu 2005; Danciu et al. 2011; Demekas et al. 2007). In addition, a lag-time certainly must occur between FDI-induced growth and GDP growth (Pelinescu \& Rădulescu 2009). However, this was not incorporated in this analysis. This lag-time could likely account for the lack of impact of FDI on economic growth at the national level as reported by Ivan \& IAcovoru (2008). It also could account for the very weak relationship between FDI and GDP at the regional level. 
Based on this study's findings, it cannot be firmly stated that inward FDI flows contribute to the reduction of regional imbalances as claimed by P. PAVLINEK in his work (2004). Although the general trend of FDI was a convergent one, it has not had the same impact on GDP in all the counties. Rank difference analyses suggest the existence of two different groupings of counties. Each of them can be characterised with the following terms: 'leading' and 'catching-up'. The boundary between the two falls in the zone of the $15^{\text {th }}-25^{\text {th }}$ counties in the hierarchy of counties by FDI stock. This boundary moves as economic growth in the various counties fluctuates.

The lower segment of each cohort, being usually characterised by higher growth rates, attempts to catch-up to the counties at the top of their respective cohort. For the upper half of the hierarchy, it is a competition between Bucharest (at the top) and Ilfov County close behind and Romania's strongest regional economies (Constanța, Timiș, Cluj, Prahova). In the lower half of the hierarchy, the tailing counties seek to catchup to the counties in the middle part. Obviously, this characterisation is based on the overall trends and does not explain all the situations. Exceptions exist.

Large cities do not play an overly important role in attracting FDI, though they remain significant, as shown by a weak correlation between the populations of county seats and FDI stock. The role of large cities is much more important in the conservation of gained advantages, which was extremely evident after the crisis occurred. Thus, since 2000, several counties have shown high growth rates of FDI in different periods: for example, Maramureș in 2000-2003, Argeș in 2000-2008, Vâlcea in 2000-2003, Cluj, Constanța, and Timiș in 2000-2003. After the financial-economic crisis, the latter three counties maintained positive, and quite high, growth rates. In contrast, Arges, Vâlcea, and Maramureș comprise a group with the largest declines in FDI stock (-13\%). Examples of other counties, not so spectacular though, just confirm this evidence.

\section{Conclusions}

The findings, presented in this paper, could not firmly support the idea that FDI was unequivocally responsible for declining regional disparities in Romania in the 2000s. Increasing disturbances played a more significant role, especially in the period of relative economic prosperity (2004-2008). No changes occurred in the hierarchical scale at the regional level in regard to attracting the FDI. However, the difference between the extremes narrow, which was largely attributed to the catch-up effect experienced by counties in the tail of the hierarchy.

Our findings also show that the relationship between the sizes of regional economies and FDI was not very strong. Thus, the sizes of the regional markets were responsible for just two-thirds of the FDI stock. Nonetheless, bigger economies, being more diversified, were more resilient during the financial-economic crisis. Moreover, county seats contributed greatly to this resilience. 
Large urban agglomerations proved not to have had as much power in attracting FDI as generally may have been assumed. Nonetheless, they were critical to the phenomenon of 'conservation', which means that they preserve investments and even assure a small but stable trend of increasing FDI stock during crises. For Romania, the eternal leader in growth rates is Bucharest.

\section{References}

Bailey D., Driffield N. (2002), Hymer and Uneven Development Revisited: Foreign Direct Investment and Regional Inequalities. In: Political Economy, 21, 1, pp. 55-68.

De Backer K., Sleuwagen L. (2003), Does Foreign Direct Investment Crowd Out Domestic Entrepreneurship? In: Journal of Industrial Organization, 22, 1, pp. 67-84.

Barro R.J., Sala-I-Martin X. (1992), Convergence. In: Journal of Political Economy, 100, pp. 223-251.

Barro R.J., Sala-i-Martin X. (2004), Economic Growth. Second edition, Cambridge, Mass., The MIT Press.

Bellak C., Leibrecht M., Riedl A. (2008), Labour costs and FDI flows into Central and Eastern European Countries: A survey of the literature and empirical evidence. In: Structural Change and Economic Dynamics, 19, pp. 17-37.

Bevan A.A., Estrin S. (2004), The determinants of foreign direct investment into European transition economies. In: Journal of Comparative Economics, 32, pp. 775-787.

BEYER J. (2002), "Please invest in our country" - how successful were the tax incentives for foreign investment in transition countries? In: Communist and Post-Communist Studies, 35, pp. 191-211.

Botric V., Skuflic L. (2006), Main Determinants of Foreign Direct Investment in the Southeast European Countries. In: Transition Studies Review, 13, pp. 359-377.

CASI L., RESMinI L. (2010), Evidence on the determinants of foreign direct investment: the case of EU regions. In: Eastern Journal of European Studies, 1, pp. 93-118.

Clausing K.A., Dorobanțu C.L. (2005), Re-entering Europe: Does European Union candidacy boost foreign direct investment? In: Economics of Transition, 13, pp. 77-103.

Damijan J.P., Kostevc C. (2011), Trade liberalisation and economic geography in CEE countries: the role of FDI in the adjustment pattern of regional wages. In: Post-Communist Economies, 23, pp. 163-189.

Danciu A.R., Goschin Z., Gruiescu M. (2010), The regional disparities of the FDI in Romania. In: Romanian Economic and Business Review, 5, pp. 23-31.

Demekas D.G., Horvath B., Ribakova E., Wu Y. (2007), Foreign direct investment in European transition economies - The role of policies. In: Journal of Comparative Economics, 35, pp. 369-386.

GURAN L. (2002), Investițiile străine directe şi dezvoltarea sistemului de așezări din România. București, Editura Tehnică.

Hirber C.A.L., Voicu I. (2010), Agglomeration Economies and the Location of Foreign Direct Investment: Empirical Evidence from Romania. In: Regional Studies, 44, pp. 355-371. 
Holland D., Sass M., Benacek V., Gronicki M. (2000), The determinants and impact of FDI in Central and Eastern Europe: A comparison of survey and econometric evidence. In: Transnational Corporations, 9, pp. 163-212.

Hudea Caraman O.S., Stancu S. (2012), Foreign Direct Investments, Technology Transfer and Economic Growth. A Panel Approach. In: Journal for Economic Forecasting, 15, pp. 85102.

IANOS I. (2010), About recent dynamics of the foreign direct investments in Romania. In: Studia Universitatis Babeș-Bolyai, Geographia, LV, pp. 139-146.

IANoș I., GuRAn L. (1993), Regionale Aspekte ausländischer Investitionen in Rumänien seit 1990. In: Österreichische Osthefte, 35, 4, pp. 633-645.

Ianoș I., Petrișor A.I., Zamfir D., CepoiU A.L., Stoica I.V., TĂlângă C. (2013), In search of a relevant index measuring territorial disparities in a transition country. Romania as a case study. In: Erde, 144, 1, pp. 69-81.

Ivan M.V., IAcovolu V. (2008), Rolul investițiilor străine directe în contextul obligativității îndeplinirii criteriilor de convergență. In: Studii Financiare, 12, pp. 73-92.

Kalotay K. (2000), Patterns of Inward FDI in Economies in Transition. In: Eastern Journal of European Studies, 1, pp. 55-76.

Kalotay K., Hunya G.. (2000), Privatization and FDI in Central and Eastern Europe. In: Transnational Corporations, 9, pp. 39-66.

Kitonakis N., Kontis A. (2008), The determinants of Greek foreign direct investments in southeast European countries. In: Southeast European and Black Sea Studies, 8, pp. 269281.

KURKo I. (2006), The regional disparities foreign direct investment in Romania. In: Romanian Review of Regional Studies, II, pp. 64-69.

Lefilleur J. (2008), Déterminants de investissements directs étrangers en Europe centrale et orientale: Un bilan de la transition. In: Revue d'études comparatives Est-Ouest, 39, pp. 201-238.

PAVLINEK P. (2004), Regional development implications of foreign direct investment in Central Europe. In: European Urban and Regional Studies, 11, pp. 47-70.

Pauwels S., Ionita L. (2008), FDI in Romania: from low-wage competition to higher valueadded sectors. In: ECFIN Country Focus, 5, pp. 1-6.

PĂUNA C.B., ANDREI D. (2004), Dimensiunea regională a determinării riscului investițiilor străine directe în România. In: Filip F.G., Simionescu B.C. (eds.), Fenomene și procese cu risc major la scara națională, pp. 225-244. București, Editura Academiei Române.

Pelinescu E., RĂdulescu M. (2009), The Impact of Foreign Direct Investment on the Economic Growth and Countries' Export Potential. In: Romanian Journal of Economic Forecasting, 12, pp. 153-169.

Roman M.D., Padureanu A. (2012), Models of Foreign Direct Investments Influence on Economic Growth. Evidence from Romania. In: International Journal of Trade, Economics and Finance, 3, pp. 25-29.

Serbu S.G. (2005), FDI Flows Towards CEECs: An Analysis on the Romania, Hungary and Slovenia's Performances. Orleans, University of Orleans - Faculty of Law and Economics, SSRN.

Smith A., Ferenčíková S. (1998), Inward Investment, Regional Transformations and Uneven Development in Eastern and Central Europe: Enterprise Case-Studies from Slovakia. In: European Urban and Regional Studies, 5, 2, pp. 155-173. 
United Nations Conference on Trade and Development (UNCTAD) (ed.) (2012). World Investment Report 2012: Towards a new generation of investment policies. New York Geneva, United Nations.

Zaman G., Vasile V., Matei M., Croitoru C., Enescu G. (2011), Some challenging (macro) economic aspects of FDI in Romania. In: Romanian Journal of Economics, 33, pp. 2158. 